\title{
A record of spontaneous subduction initiation in the Izu-Bonin-Mariana arc
}

\author{
Richard J. Arculus ${ }^{1 *}$, Osamu Ishizuka ${ }^{2,3}$, Kara A. Bogus ${ }^{4}$, Michael Gurnis ${ }^{5}$, Rosemary \\ Hickey-Vargas ${ }^{6}$, Mohammed H. Aljahdali ${ }^{7}$, Alexandre N. Bandini-Maeder ${ }^{8}$, Andrew P. \\ Barth $^{9}$, Philipp A. Brand1 ${ }^{1,10}$, Laureen Drab ${ }^{11}$, Rodrigo do Monte Guerra ${ }^{12}$, Morihisa \\ Hamada $^{13}$, Fuqing Jiang ${ }^{14}$, Kyoko Kanayama ${ }^{15}$, Sev Kender ${ }^{16,17}$, Yuki Kusano ${ }^{15}$, He Li ${ }^{18}$, \\ Lorne C. Loudin ${ }^{19}$, Marco Maffione ${ }^{20}$, Kathleen M. Marsaglia ${ }^{21}$, Anders McCarthy ${ }^{22}$, \\ Sebastién Meffre $^{23}$, Antony Morris ${ }^{24}$, Martin Neuhaus ${ }^{25}$, Ivan P. Savov ${ }^{26}$, Clara Sena ${ }^{27}$, \\ Frank J. Tepley III $^{28}$, Cees van der Land ${ }^{29}$, Gene M. Yogodzinski ${ }^{30}$, Zhaohui Zhang ${ }^{31}$
}

${ }^{1}$ Research School of Earth Sciences, Australian National University, Canberra ACT 2601, Australia. ${ }^{2}$ Geological Survey of Japan/AIST, Central 7 1-1-1 Higashi, Tsukuba, Ibaraki 305-8567, Japan. ${ }^{3}$ Research and Development Center for Ocean Drilling Science, Japan Agency for Marine-Earth Science and Technology, 2-15 Natsushimacho, Yokosuka 237-0061, Japan. ${ }^{4}$ International Ocean Discovery Program, Texas A\&M University, 1000 Discovery Drive, College Station, TX 77845-9547, USA. ${ }^{5}$ Division of Geological and Planetary Sciences, California Institute of Technology, 1200 East California Boulevard, MC 2520-21, Pasadena, CA 91125, USA. ${ }^{6}$ Earth and Environment Department, Florida International University, Modesto Maidique Campus, AHC5-394, Miami, FL 33199, USA. ${ }^{7}$ Department of Earth, Ocean and Atmospheric Science, Florida State University, 108 Carraway Building, Woodward Street, Tallahassee, FL 32306-0001, USA. ${ }^{8}$ Center for Energy Geoscience, School of Earth and Environment, University of Western Australia, 35 Stirling Highway, Perth, Western Australia 6009, Australia. ${ }^{9}$ Department of Earth Sciences, Indiana University-Purdue University, 723 West Michigan Street, Indianapolis, IN 46202, USA. ${ }^{10}$ Geozentrum Nordbayern, Friedrich-Alexander-Universität Erlangen-Nürnberg, Schlossgarten 5, 91054 Erlangen, Germany. ${ }^{11}$ Borehole Research Group, Lamont-Doherty Earth Observatory of Columbia University, PO Box 1000, 61 Route 9W, Palisades, NY 10964, USA.

${ }^{12}$ Technological Institute of Micropaleontology, University of Vale do Rio dos Sinos, Bloco 6K, Avenue Unisinos, 950-B Cristo Rei, Sao Leopoldo 93022, Brazil. ${ }^{13}$ Department of Solid Earth Geochemistry, Japan Agency for Marine-Earth Science and Technology, 2-15 Natsushima-cho, Yokosuka 237-0061, Japan. ${ }^{14}$ Institute of Oceanology, Chinese Academy of Sciences, 7 Nanhai Road, Qingdao 266071, P.R. China. ${ }^{15}$ College of Science and Engineering, Kanazawa University, Kakuma-machi, Kanazawa, Ishikawa 920-1192, Japan. ${ }^{16}$ School of Geography, University of Nottingham, University Park, Nottingham NG7 2RD, United Kingdom. ${ }^{17}$ British Geological Survey, Keyworth, Nottingham, NG12 5GG, United Kingdom. ${ }^{18}$ Guangzhou Institute of Geochemistry, Chinese Academy of Sciences, 511 Kehua Street, Guangzhou 510640, P.R. China. ${ }^{19}$ Department of Earth Sciences, University of New Hampshire, 56 College Road, 214 James Hall, Durham, NH 03824, USA. ${ }^{20}$ Institute of Earth Sciences, Utrecht University, Budapestlaan 17, Utrecht 3584, The Netherlands. ${ }^{21}$ Department of Geological Sciences, California State University, 18111 Nordhoff Street, Northridge, CA 91330-8266, USA. ${ }^{22}$ Institute of Earth Sciences, University of Lausanne, Geopolis, Lausanne 1015, Switzerland. ${ }^{23}$ School of Earth Sciences, University of Tasmania, Hobart TAS 7001, Australia. ${ }^{24}$ School of Geography, Earth and Environmental Sciences, Plymouth University, Drake Circus, Plymouth PL4 8AA, United Kingdom. ${ }^{25}$ Institut 
für Geophysik und Extraterrestrische Physik, Technische Universität Braunschweig, Medelssohnstrasse 3, Braunschweig 38106, Germany. ${ }^{26}$ School of Earth and Environment, University of Leeds, Leeds LS2 9JT, United Kingdom. ${ }^{27}$ Geosciences Department/CESAM, Universidade de Aveiro, Campus Universitario Santiago, 3810-193 Aveiro, Portugal. ${ }^{28}$ College of Earth, Ocean and Atmospheric Sciences, Oregon State University, 104 CEOAS Administration Building, Corvallis OR 97331, USA. ${ }^{29}$ School of Civil Engineering and Geosciences, University of Newcastle, Newcastle upon Tyne NE1 7RU, United Kingdom. ${ }^{30}$ Department of Earth \& Ocean Sciences, University of South Carolina, 710 Sumter Street, EWSC617, Columbia SC 29208, USA. ${ }^{31}$ Earth Sciences, Nanjing University, 22 Hankou Road, Nanjing 210093, P.R. China.

*Corresponding author. E-mail: richard.arculus@anu.edu.au

The initiation of tectonic plate subduction into the mantle is poorly understood. If subduction is induced by the push of a distant mid-ocean ridge or subducted slab, we expect compression and uplift of the overriding plate. In contrast, spontaneous subduction initiation, driven by subsidence of dense lithosphere along faults adjacent to buoyant lithosphere, would result in extension and magmatism. The rock record of subduction initiation is typically obscured by younger deposits, so evaluating these possibilities has proved elusive. Here we analyse the geochemical characteristics of igneous basement rocks and overlying sediments, sampled from the Amami Sankaku Basin in the northwest Philippine Sea. The uppermost basement rocks are areally widespread and supplied via dykes. They are similar in composition and age - as constrained by the biostratigraphy of the overlying sediments - to the 52-48 million-year-old basalts in the adjacent Izu-BoninMariana fore-arc. The geochemical characteristics of the basement lavas indicate that a component of subducted lithosphere was involved in their genesis and the lavas were derived from mantle source rocks that were more melt-depleted than those tapped at midocean ridges. We propose that the basement lavas formed during the inception of IzuBonin-Mariana subduction in a mode consistent with the spontaneous initiation of subduction.

Recycling of lithospheric plates into the mantle is a major driver of the physical and chemical evolution of Earth. Subduction zones mark sites of lithosphere insertion into Earth's mantle but we do not have a good understanding of how these zones are initiated or the accompanying compositional types and style of magmatism. Of all magma types emplaced at or near the surface of the Earth, those associated with subduction zones most closely match the average continental crust $^{1}$; accordingly there has been sustained interest in the genesis and evolution of island arc 
magmas, and their significance with respect to continental crustal growth. On the basis of assumed ages of the current major subduction systems bordering the Pacific and along the AlpineHimalayan Zone, McKenzie ${ }^{2}$ suggested "ridges start easily, but trenches do not." Ignorance of subduction inception contrasts with our advanced understanding of oceanic crust creation from initial lithospheric rifting to development of a mid-ocean ridge. Gurnis et al. ${ }^{3}$ noted half of all active subduction zones initiated in the Cenozoic in a variety of tectonic settings including old fracture zones, transform faults, extinct spreading centers, and through polarity reversals behind active subduction zones, and concluded forces resisting subduction can be overcome in diverse settings accompanying the normal evolution of plate dynamics.

Among a number of proposed hypotheses, two general mechanisms, induced or spontaneous ${ }^{3,4}$, seem relevant to initiation of one of the largest intra-oceanic subduction zones in the western Pacific, namely the Izu-Bonin-Mariana (IBM) system. Induced subduction initiation leading to self-sustaining descent of lithosphere into the mantle results from convergence forced by external factors such as ridge push or slab pull along strike of a given system ${ }^{\text {e.g. } 3}$. The Puysegur Ridge south of New Zealand may be an example. Stern ${ }^{4}$ suggested the IBM system represents an example of spontaneous initiation wherein subsidence of relatively old Pacific lithosphere commenced along a system of transform faults/fracture zones adjacent to relatively young, buoyant lithosphere. The importance of transpressional forces in subduction initiation has also been emphasised ${ }^{5}$. Stern and Bloomer ${ }^{6}$ proposed the earliest stages of volcanism accompanying spontaneous subduction zone nucleation are rift-associated and extensive perpendicular to the strike of the zone, rather than comprising the archetypal chain of stratovolcanoes that dominate mature arcs. The initial record of subduction initiation on the overriding plate resulting from these competing hypotheses should be distinct: induced subduction likely results in strong compression and uplift shedding debris into nearby basins, whereas spontaneous subduction commences with basement deepening prior to rifting, and sea-floor spreading potentially analogous to a number of ophiolites $^{\text {e.g. } 3,6}$.

For the IBM system, the age and composition of initial magmatism $(\sim 52 \mathrm{Ma})$ preserved in the forearc basement and underlying peridotite have been determined ${ }^{7}$, as has the subsequent magmatic evolution of the arc via study of dredged and drilled materials including ashes and pyroclastics recovered by ocean drilling ${ }^{8,9}$. The arc has experienced episodes of backarc spreading in the Mariana Trough (7 Ma to present) and Shikoku and Parece Vela basins ( 30-20 Ma), resulting in abandonment of the Kyushu-Palau Ridge (KPR) as a remnant $\operatorname{arc}^{10}$. Understanding the relationship of the northern portion of the KPR to the basement underlying its western flank in the Amami Sankaku Basin (ASB; Fig. 1) appeared to offer the promise of a record of IBM 
inception complementary to that recovered by dredging and submersible operations in the forearc ${ }^{7}$. Taylor \& Goodliffe ${ }^{10}$ for example, had emphasized the strike of the KPR in this region (and the inferred Eocene trench) is at a high angle to all major extant features such as the western and southern borders of the ASB, and Amami Plateau-Daito Ridge, and concluded the IBM subduction zone did not initiate along any part of the preexisting tectonic fabric such as a transform fault.

\section{The Amami-Sankaku Basin - a key record of IBM arc inception}

The ASB is in the northwest of the Philippine Sea plate (PSP). The PSP is bounded by subduction zones and transform faults (Fig. 1), and has a complex tectonic and magmatic history. Plate tectonic reconstructions ${ }^{11-13}$ place subduction inception at $\sim 50 \mathrm{Ma}$ in the proto-Izu-Bonin arc (i.e., previously assumed to be the KPR), concurrent Pacific plate motion change, cannibalizing former northwest-southeast-trending transform faults associated with the Izanagi-Pacific Ridge (e.g., ref 14). Whittaker et al. ${ }^{12}$ propose subduction of the Izanagi-Pacific Ridge along eastern Asia at $\sim 60$ Ma initiated plate reorganisation culminating in Pacific plate motion change at 50 Ma relative to the Eurasian plate. Since IBM inception, the PSP has migrated northward accompanied by clockwise rotation, mostly between 50 and $25 \mathrm{Ma}^{15}$. At subduction inception, a Cretaceous-age island arc system existed on the PSP, now preserved as the Amami Plateau-Daito-Oki Daito ridges ${ }^{13}$ (Fig.1); arc conjugates are likely preserved in the southern PSP in Halmahera and southern Moluccas ${ }^{16}$. Backarc spreading behind this southern arc caused initial opening of the West Philippine Basin (WPB), isolating the Amami Plateau-Daito-Oki Daito ridges. Plumederived ocean island basalt (OIB)-like magmatism followed IBM initiation, endured from 51 to $45 \mathrm{Ma}$, and is preserved as the Benham Rise-Urdaneta Plateau-Oki Daito Rise ${ }^{17-19}$.

The ASB floor has a simple structure comprising up to $1.5 \mathrm{~km}$ of sediment overlying igneous oceanic crust (Fig. 2). Assuming a $\mathrm{V}_{\mathrm{p}} \sim 6 \mathrm{kms}^{-1}$, the two-way travel time of nearly 2 seconds to Moho indicates normal oceanic crustal thickness of about $6 \mathrm{~km}$ (Figure S1). There is no indication from available seismic lines that major topography such as stratovolcanoes forms the ASB basement. The floor of the basin is shallower than other basins west of the KPR and the WPB $^{\text {e.g. } 10}$. International Ocean Discovery Program (IODP) Expedition 351 targeted the ASB anticipating the earliest stages of arc inception and evolution of the northern IBM arc would be preserved in the recovered sedimentary record. The basement composition and age would constrain the petrological, geochemical and tectonic evolution of the arc and subduction zone initiation. By extrapolation of the ASB basement seismic characteristics beneath the KPR, the structure of the IBM arc as a whole could be determined. Prior to Expedition 351, it appeared the 
early ASB sediment and basement might be Paleogene ${ }^{20}$ or even Cretaceous in age. During Expedition 351, IODP Site U1438 (4700 m water depth) penetrated $1461 \mathrm{~m}$ of sediments and sedimentary rocks and $150 \mathrm{~m}$ of the underlying igneous basement of the ASB. In terms of subduction inception, the nature of the basement and immediately overlying sedimentary rocks are critical and presented here. The results were unexpected, and require reappraisal of the style of arc magmatism immediately following inception, and of the significance of the large volume of subduction-related basaltic crust associated with this intra-oceanic island arc.

\section{The Amami-Sankaku Basin basement and overlying sediments}

A rubbly contact is present between overlying brown laminated mudstone and underlying, oxidized basalt. Overall, the ASB basement comprises variably altered and veined, lava sheet flows of sparsely vesicular to non-vesicular, microcrystalline to fine-grained, aphyric to sparsely microphyric, high-Mg, low-Ti, tholeiitic basalts. Phenocrysts are present in $\sim 50 \%$ of samples, and consist of plagioclase, clinopyroxene, titanomagnetite, and olivine in order of decreasing abundance. Several chilled flow margins are present, but few preserve glassy margins. Petrologic details and representative photomicrographs (Fig. S2) are given in the Supplementary Information.

Bulk compositions determined shipboard by inductively coupled plasma atomic emission spectrometry are presented in Table S1. The basalts mostly have high-MgO (generally $>8 \mathrm{wt} \%$ ), low- $\mathrm{TiO}_{2}(0.6-1.1 \mathrm{wt} \%)$, low-Zr (mostly $\left.<50 \mathrm{ppm}\right)$, high-Sc (mostly $>40 \mathrm{ppm}$ ) and high-Cr (up to $\sim 400 \mathrm{ppm})$. These basalts are compositionally distinct compared with mid-ocean ridge basalts (MORB) but generally similar to the $\sim 48$ Ma basalts recovered at Site 1201 (Ocean Drilling Program Leg 195) in the West Philippine Basin $^{21}$ (Fig. 1), the $\sim 52$ Ma tholeiitic basalts (termed fore-arc basalts; FAB) recovered from the IBM Trench slope ${ }^{22-25}$ (Fig. 1) and recently in the IzuBonin forearc by IODP Expedition $352^{26}$ Fig. 4, Figs S3-4).

The lowermost sedimentary rocks (Unit IV) overlying the basement are clearly critical in terms of the earliest record of adjacent volcanic edifices, such as the developing KPR. Immediately above basement is a 4 m-thick section of dark reddish mudstone and sandstone passing upwards to fine to coarse tuffaceous rocks, and then fine to medium to coarse sandstone and breccia-conglomerate. The lithologic and paleontologic details are given in the Supplementary Information. A summary biostratigraphic- and paleomagnetic-based age-depth plot for the sediments at Site U1438 is shown in Figure 3. Based on the biostratigraphic data, the calculated average sedimentation rate for the lowermost $70 \mathrm{~m}$ of the supra-basement sediments is between 2 to $14 \mathrm{~mm} / \mathrm{ka}$ without considering compaction. Allowing for a 
compaction factor ranging from 3 to 5 , the average sedimentation rate would be between 6 to $69 \mathrm{~mm} / \mathrm{ka}$. On that basis, the minimum age of the uppermost basement is inferred to be between 51 to $64 \mathrm{Ma}$, with a probable age around $55 \mathrm{Ma}$. Consistent with the biostratigraphic constraints, in situ downhole temperature measurements and thermal conductivity measurements on core material to $85 \mathrm{~m}$ depth beneath the sea floor give a calculated heat flow of $73.7 \mathrm{~mW} / \mathrm{m}^{2}$ (Fig. S3), implying a thermal age for the underlying lithosphere of 40-60 $\mathrm{Ma}^{27}$.

\section{Subduction inception and earliest magmatism of the IBM arc}

Prior to Expedition 351, we expected ASB basement rocks to be 10 s of millions of years older than the IBM arc inception date (52 Ma according to forearc exposures ${ }^{23}$ ), and potentially bounded on the western margin of the ASB by an old transform fault. Two other assumptions prevailed: (1) the tectonic setting of the basement was assumed to be non-arc related, given its depth relative to nearby inter-ridge and backarc basins, and relatively smooth morphology (Fig. 1); (2) the strike of the KPR stratovolcanic edifices (proto-IBM arc) is subparallel to the nascent IBM trench and at an angle to the bounding features of the ASB or neighbouring Cretaceous-aged arcs, suggesting a locus for initial arc magmatism independent of the immediate ASB basement origins or tectonic setting ${ }^{10}$.

Drilling results at Site U1438 have defied expectations, and none of these assumptions now appear valid. There is marked geochemical and petrological equivalence of the igneous basement at sites U1438, 1201 and the FAB of the present-day IBM forearc ${ }^{21-24,26,28}$. Compared with $\mathrm{MORB}^{29}$, Site U1438 basalts are notable for the presence of phenocryst clinopyroxene (cf. pyroxene paradox ${ }^{30,31}$ ), high $\mathrm{MgO} / \mathrm{FeO}$, markedly low $\mathrm{TiO}_{2}$, low $\mathrm{Zr}$, and high $\mathrm{Sc}$ abundances. The tholeiitic basalts in both present-day forearc and ASB were likely derived from upper mantle sources more strongly depleted in terms of magmaphile trace elements than those typically tapped beneath mid-ocean ridges. The critical distinctive characteristics of these basalt types compared with MORB are their low $\mathrm{Zr} / \mathrm{Y}$ and $\mathrm{Ti} / \mathrm{V}$ (Fig. 4). These characteristics relate to the tapping of a more refractory (prior melt-depleted) mantle source and presumably more oxidized melting conditions than those beneath mid-ocean ridges ${ }^{33-36}$. It is noteworthy however, that the Ti/V of FAB from the IBM forearc are lower than those of Site U1438 and 1201, and overlap those of Site A (Fig. 1) in the fore-arc (Fig. S4), possibly indicative of decreasing mantle wedge oxidation from trench-proximal to distal across the strike of the nascent IBM arc. While there is muted development of $\mathrm{Pb}$ and other fluid-mobile, lithophile trace element spikes ${ }^{23,24}$, the involvement of subducted slab-derived fluids in the genesis of FAB is implicated by: (1) the "spoon-shaped" rare 
earth element abundance patterns compared with mid-ocean ridge basalts ${ }^{29} ;(2)$ the presence of clinopyroxene phenocrysts relating to relative suppression of plagioclase saturation resulting from elevated $\mathrm{H}_{2} \mathrm{O}$ contents; and (3) depleted character of the mantle source(s), plausibly requiring fluid fluxing for melting. Basalts from Site 447 (Fig. 1; on magnetic anomaly 22, 44Ma) in the West Philippine Basin have a depleted character similar to $\mathrm{FAB}^{32}$, but also normal olivineplagioclase phenocryst assemblages characteristic of MORB, and lack clinopyroxene, plausibly reflecting low dissolved $\mathrm{H}_{2} \mathrm{O}$ contents. The important point is the specific ensemble of petrologic characteristics of FAB is unequivocally related to subduction zone magmatism, albeit at an early stage of development in any given arc setting. We note tholeiitic basalts derived from refractory mantle sources equivalent to those tapped during FAB genesis are being erupted in some active rear arc settings. For example, those of the Fonualei Rifts adjacent to the northernmost Tonga Arc have strikingly low $\mathrm{Zr} / \mathrm{Y}$ and $\mathrm{Ti} / \mathrm{V} 10<20$ equivalent to those of $\mathrm{FAB}^{37}$, but are also characterized by more strongly elevated $\mathrm{Pb} / \mathrm{Ce}$ and other indicators of a larger slab-derived, large ion lithophileenriched fluid component in their genesis than FAB.

We conclude on the basis of available age constraints, probable sheet lava flow morphology, petrology, and key geochemical characteristics that the basement of the ASB is equivalent to the FAB exposed in the trench slope of the IBM arc. We recognize that radiometric dating of the ASB basement is required, and may temporally have preceded the FAB exposed in the present-day fore arc. Reconstruction of the nascent IBM arc then implies an across arc-strike extent for FAB and basement of the ASB of at least $\sim 250 \mathrm{~km}$, after accounting for backarc extension. The multiple feeder dike systems of FAB observed in the trench slope are all consistent with an origin for these basalts in a tectonic environment characterized by sea floor spreading. The seismic structure of the KPR indicates the igneous basement at sites $1201^{38}$ and U1438 ${ }^{39}$ continues beneath the Ridge, and there is an absence of the thick $(>5 \mathrm{~km})$ middle crustal layer with $\mathrm{V}_{\mathrm{p}} \sim 6 \mathrm{kms}^{-1}$ (plausibly dioritic) that characterizes the active IBM $\operatorname{arc}^{40}$. Sediments overlying the ASB basement contain an increasing volumetric input from adjacent arc edifices, inferred to be the developing stratovolcanoes of the KPR but possibly from activity on adjacent Daito ridges and Amami Plateau. The KPR volcanoes have no apparent or simple relationship with any of the observable tectonic features of the basement upon which they are superimposed. Similar indifference with respect to basement features is manifest globally by many island and continental arc chains of volcanoes. The assumption that the strike of the KPR precludes models of subduction initiation along a preexisting zone of weakness is erroneous because the local ASB basement (lava flows) was not formed prior to the development of subduction. In fact, the ASB basement has either blanketed any preexisting basement or if formed through seafloor spreading, 
represents $100 \%$ new crust. The evidence that the western boundary of the ASB is a N-S-striking transform fault is not proven, and could postdate at least in part formation of the ASB.

An important corollary is much of the areally extensive, basaltic crust of the earliest IBM arc was constructed by subduction-related processes rather than at a pre- 52 Ma mid-ocean ridge. The limited presence of Jurassic (159 Ma) arc-type tholeiites in the IBM trench slope ${ }^{23}$ is an indication that the $\sim 52 \mathrm{Ma}$-old crust developed in rifted older arc basement. Previous attempts at calculating volumetric fluxes in the IBM system have deducted a basement crustal thickness equivalent to that of ordinary, mid-ocean ridge-generated crust ${ }^{41}$; this potentially results in underestimation of the volumetric flux for the early IBM arc, which may have been equivalent for a few million years of early arc growth to that of mid-ocean ridges $\left(\sim 1000 \mathrm{~km}^{3} \mathrm{~km}^{-1} \mathrm{Ma}^{-1}\right)$.

Clearly, our general conceptions of the earliest stages of intra-oceanic arc development need substantial modification. Suggestions ${ }^{\text {e.g. } 6}$ that the post-FAB sequences of boninite pillow lava and dyke outcrops at the type locality at Chichijima and at ODP Site 786 (both in the IBM forearc) developed in an extensional environment with no localization of archetypal stratovolcano edifices, are confirmed and amplified by the identification of widespread preceding eruptions of tholeiitic basalts. The latter formed the basement on which a restricted across-strike distribution of individual stratovolcanoes was developed, preserved in the remnant arc of the KPR. The apparent absence of boninite lithologies at Site U1438 may reflect a trenchward-restriction and focusing of wedge melting as the arc developed.

Overall, it appears major motion changes of the Pacific plate following subduction of the Izanagi-Pacific Ridge along East Asia led to reorganization of equatorially-located networks of island arc systems in the region between the Australian and Asian plates ${ }^{42}$. The Philippine Sea plate developed in this region, and experienced trench roll-back at one or more of its bounding plate margins ( $\sim 60 \mathrm{Ma}$ ). Subduction initiation at $\sim 52 \mathrm{Ma}$ at the future site of the IBM system, triggered rifting and seafloor spreading of the overriding plate, forming an extensive basaltic arc crust, both along- and across-strike. Localization of a defined chain of stratovolcanoes atop this basement later formed a volcanic front. Areally extensive basaltic crust with unequivocal subduction zone-related petrological and geochemical signatures is consistent with a spontaneous subduction initiation mechanism ${ }^{6}$ but not at a pre-existing fracture zone (e.g, ref 10).

It is still possible the ASB formed through spreading in a marginal basin associated with subduction earlier than IBM inception, but structural relationships of the basin with surrounding ridges do not clearly indicate such an association. Rather than across-strike variation in mantle processes, the additional geochemical data indicate potential along-strike 
influences. Closure of the Shikoku Basin shows the ASB and site U1438 are conjugate to site A in the IB fore-arc (Fig. 1) whereas Site B, Expedition 352, and the Bonin (forearc) Ridge are conjugate to the Daito and Oki-Daito ridges; a greater subduction-related influence on the mantle prior to IBM inception may be expected for these latter sites, consistent with their lower $\mathrm{Ti} / \mathrm{V}$.

Finally, we note a forced subduction initiation is not altogether precluded because while evidence for a pre-subduction initiation basement is not widespread, it may exist. These uncertainties require resolution by detailed multidisciplinary studies of samples recovered by the triplet of IODP expeditions (350-352) to the IBM system.

\section{Methods}

All data generated during IODP Expedition 351 will be publicly accessible from 31 July 2015 via the IODP-JOIDES Resolution Science Operator website (www.iodp.tamu.edu).

\section{References}

1. Taylor, S.R. The origin and growth of continents. Tectonophysics 4(1), 17-34 (1967).

2. McKenzie, D.P. The initiation of trenches: a finite amplitude instability. In Talwani, M., and Pitman, W.C., IIII (Eds.), Island Arcs, Deep Sea Trenches and Back-Arc Basins. Maurice Ewing Series, 1, 57-61 (1977).

3. Gurnis, M., Hall, C. \& Lavier, L. Evolving force balance during incipient subduction. Geochem. Geophys. Geosyst. 5, Q07001 (2004).

4. Stern, R.J. Subduction initiation: spontaneous and induced. Earth Planet. Sci. Lett. 226, 275-292 (2004).

5. Eakin, D.H., McIntosh, K.D., Van Avendonk, H.J.A. \& Lavier, L. New geophysical constraints on a failed subduction initiation: the structure and potential evolution of the Gagua Ridge and Huatung Basin. Geochem. Geophys. Geosyst. 16, 380-400 (2015).

6. Stern, R.J. \& Bloomer, S.H. Subduction zone infancy: examples from the Eocene Izu-Bonin-Mariana and Jurassic California arcs. Geol. Soc. Am. Bull. 104, 1621-1636 (1992).

7. Ishizuka, O. et al. The timescales of subduction initiation and subsequent evolution of an oceanic island arc. Earth Planet. Sci. Lett. 306, 229-240 (2011).

8. Bryant, C.J., Arculus, R.J. \& Eggins, S.M. Laser ablation-inductively coupled plasma-mass spectrometry and tephras: a new approach to understanding arc-magma genesis. Geology 27, 1119-1122 (1999).

9. Straub, S.M. The evolution of the Izu Bonin-Mariana volcanic arcs (NW Pacific) in terms of major elements. Geochem. Geophys. Geosyst. 4, 1018 (2003).

10. Taylor, B., and Goodliffe, A.M. The West Philippine Basin and the initiation of subduction, revisited. Geophys. Res. Lett. 31, L12602 (2004).

11. Deschamps, A. \& Lallemand, S. The West Philippine Basin: an Eocene to early Oligocene back arc basin openend between two opposed subduction zones. J. Geophys. Res. 107, 2322 (2002). 
12. Whittaker, J.M. et al. Major Australian-Antarctic plate reorganization at Hawaiian-Emperor Bend time. Science 318, 83-86 (2007).

13. Seton, M. et al. Global continental and ocean basin reconstructions since 200 Ma. Earth-Sci. Revs. 113, 212$270(2012)$.

14. Uyeda, S., and Ben-Avraham, Z. Origin and development of the Philippine Sea. Nature, 240, 176-178 (1972).

15. Yamazaki, T. et al. Philippine Sea plate motion since the Eocene estimated from paleomagnetism of seafloor drill cores and gravity cores. Earth, Planets and Space 62, 495-502 (2010).

16. Hall, R., Nichols, G., Balantyne, P., Charlton, T. \& Ali, J. The character and significance of basement rocks of the southern Molucca Sea region. J. Southeast Asian Earth Sci. 6, 249-258 (1991).

17. Hickey-Vargas, R. Basalt and tonalite from the Amami Plateau, northern West Philippine Basin: new Early Cretaceous ages and geochemical results, and their petrologic and tectonic implications Island Arc 14, 653-665 (2005).

18. Macpherson, C.G. \& Hall, R. Tectonic setting of Eocene boninite magmatism in the Izu-Bonin-Mariana forearc. Earth Planet. Sci. Lett. 186, 215-230 (2001).

19. Ishizuka, O., Taylor, R.N., Ohara, Y. \& Yuasa, M. Upwelling, rifting, and age-progressive magmatism from the Oki-Daito mantle plume. Geology 41, 1011-1014 (2013).

20. Higuchi, Y. et al. 2007. Cenozoic stratigraphy and sedimentation history of the northern Philippine Sea based on multichannel seismic reflection data. Island Arc 16, 374-393 (2007).

21. Savov, I.P., Hickey-Vargas, R., D’Antonio, M., Ryan, J.G. \& Spadea, P. Petrology and geochemistry of West Philippine Basin basalts and early Palau-Kyushu arc volcanic clasts from ODP Leg 195, Site 1201D: implications for the early history of the Izu-Bonin-Mariana arc. J. Petrol. 47, 277-299 (2006).

22. DeBari, S.M., Taylor, B., Spencer, K. \& Fujioka, K. A trapped Philippine Sea plate origin for MORB from the inner slope of the Izu-Bonin Trench. Earth Planet. Sci. Lett. 174,183-197 (1999).

23. Ishizuka, O., et al. Early stages in the evolution of Izu-Bonin arc volcanism: new age, chemical, and isotopic constraints. Earth Planet. Sci. Lett. 250, 385-401 (2006).

24. Reagan, M.K., et al. Fore-arc basalts and subduction initiation in the Izu-Bonin-Mariana system. Geochem. Geophys. Geosyst. 11, Q03X12 (2010).

25. Meijer, A., Anthony, E. \& Reagan, M. Petrology of volcanic rocks from the fore-arc sites. Initial Reports Deep Sea Drilling Project 60, 709-730 (1982).

26. Expedition 352 Scientists. Izu-Bonin-Mariana fore arc: testing subduction initiation and ophiolite models by drilling the outer Izu-Bonin-Mariana fore arc. International Ocean Discovery Program Preliminary Report 352, http://dx.doi.org/10.14379/iodp.pr.352.2015 (2015).

27. Sclater, J.G., Jaupart, C. \& Galson, D. The heat flow through oceanic and continental crust and the heat loss of the Earth. Revs. Geophys. Space Phys. 18, 269-311 (1980).

28. Ishizuka, O., Taylor, R.N., Yuasa, M. \& Ohara, Y. Making and breaking an island arc: a new perspective from the Oligocene Kyushu-Palau arc, Philippine Sea. Geochem. Geophys. Geosyst. 12, Q05005 (2011).

29. Jenner, F.E. \& O’Neill, H.St.C. Analysis of 60 elements in 616 ocean floor basaltic glasses. Geochem. Geophys. Geosyst. 13, Q02005 (2012). 
30. Rhodes, J.M. et al. Magma mixing at mid-ocean ridges: evidence from basalts drilled near $22^{\circ} \mathrm{N}$ on the MidAtlantic Ridge. Tectonophysics 55, 35-61 (1979).

31. Sinton, J.M. \& Detrick, R.S. Mid-ocean ridge magma chambers. J. Geophys. Res. 97, 197-216 (1992).

32. Mattey, D.P., Marsh, N.G. \& Tarney, J. The geochemistry, mineralogy, and petrology of basalts from the West Philippine and Parece Vela basins and from the Palau-Kyushu and West Mariana ridges, Deep Sea Drilling Project Leg 59. Proc. DSDP Init. Repts.59, 753-800 (1981).

33. Mallman, G. \& O’Neill, H.StC. The crystal/melt partitioning of V during mantle melting as a function of oxygen fugacity compared with some other elements (Al, P, Ca, Sc, Ti, Cr, Fe, Ga, Y, Zr and Nb). J. Petrol. 50, 1765-1794 (2009).

34. Lee, C-T. et al. The redox state of arc mantle using Zn/Fe systematics. Nature 468, 681-685 (2010).

35. Evans, K.A. The redox budget of subduction zones. Earth-Sci. Revs. 113, 11-32 (2012).

36. Shervais, J.W. Ti-V plots and the petrogenesis of modern and ophiolitic lavas. Earth Planet. Sci. Lett. 59, 101118 (1982).

37. Keller, N., Arculus, R.J., Hermann, J. \& Richards, S. Submarine back-arc lava with arc signature: Fonualei Spreading Centre, northeast Lau basin, Tonga. J. Geophys. Res. 113, B08S07 (2007).

38. Nishizawa, A., Kaneda, K., Katagiri, Y. \& Kasahara, J. Variation in crustal structure along the Kyushu-Palau Ridge at $15-21^{\circ} \mathrm{N}$ on the Philippine Sea plate based on seismic refraction profiles. Earth Planets Space 59, $17-$ 20 (2007).

39. Kaneda, K., Nishizawa, A. \& Oikawa, M. Large-scale seismic experiments conducted by Japan Coast Guard in the northwestern Pacific plate and the Philippine Sea plate. Journal of Geography in press, (2015).

40. Suyehiro, K. et al. Continental crust, crustal underplating, and low-Q upper mantle beneath an oceanic island arc. Science 272, 390-392 (1996).

41. Arculus, R.J. Origins of the continental crust. Journal and Proceedings of the Royal Society of New South Wales 132, 83-110 (1999).

42. Hall, R. Late Jurassic-Cenozoic reconstructions of the Indonesian region and the Indian Ocean. Tectonophysics 570-571, 1-41 (2012).

43. Gale, A. et al. The mean composition of ocean ridge basalts. Geochem. Geophys. Geosyst. 14, 489-518 (2013).

\section{Acknowledgements}

This research used samples and data provided by the International Ocean Discovery Program. We thank the USIO staff and the SIEM Offshore crew for their invaluable assistance and skill during the Expedition. Funding was provided by the Australian Research Council and the ANZIC office to R.J.A. Additional funding was provided to M.A. by the Ministry of Education of Saudi Arabia, and to A.B-M. by Fugro AG. We gratefully acknowledge the initial inspiration and ongoing advice of Brian Taylor and the drilling proposal proponents, whose efforts led to IODP 
Expedition 351. We thank Sherm Bloomer and Brian Taylor for their highly constructive comments and suggestions.

\section{Author contributions}

All co-authors were participants on IODP Expedition 351 and participated in generating the data published herein, the data analysis and interpretation, and contributed to the writing of this manuscript. Specifically: R.J.A., O.I., and K.B. planned and implemented the expedition; A.P.B., P.A.B., R.L.H.-V., F.J., K.K., Y.K., H.L., K.M.M., A.M., S.M., I.P.S., F.J.T., and G.M.Y. generated the lithologic data; M.H.J., A.N.B.-M., R.G., and S.K. performed the biostratigraphy; M.M. and A.M. performed the magnetostratigraphy; L.D., M.C.G., M.H., and M.N. calculated the thermal age of basement; and, L.L., C.A.S, C.L., and Z.Z. generated the geochemical data.

\section{Additional information}

Supplementary information is available in the online version of the paper. Reprints and permissions information is available online at www.nature.com/reprints. Correspondence should be addressed to R.J.A.

\section{Competing financial interests}

The authors declare no competing financial interests

Figure captions

Figure 1. Location of the Amami Sankaku Basin and the Kyushu-Palau Ridge. General setting and bathymetry (blue deep, red shallow) of the bounding trenches, basins, and ridges comprising the Philippine Sea Plate, boundary outlined with a dashed white line. Locations of IODP Site U1438, ODP Site 1201, and DSDP Site 447 are shown by pink stars. Locations of Shinkai submersible dives in the IBM forearc are noted as $\mathrm{A}^{22}, \mathrm{~B}^{23}$, and $\mathrm{D}^{24}$. Location of DSDP Site 458 is noted as $C^{25}$. Pink-bounded box is shown in detail in Figure 2.

Figure 2. Detailed bathymetry of the Amami Sankaku Basin, IODP Site U1438, and seismic survey lines. Bathymetry of the Amami Sankaku Basin, neighboring Kyushu-Palau Ridge, and nearby Cretaceous-aged arcs of the Amami Plateau and Daito Ridge. Site U1438 is located at the intersection of the two multichannel seismic survey lines D98-A and D98-8 
(a). Seismic reflection images (b) at Site U1428 showing in the two upper subpanels, the multichannel seismic line D98-8 (upper) and interpreted major reflectors (lower). Lower two subpanels show multichannel seismic line D98-A (upper) and interpreted major reflectors (lower).

Figure 3. Graphic lithologic summary, biostratigraphic- and paleomagnetic-based agedepth plot for IODP Site U1438. Abbreviations are: $\mathrm{mbsf}=$ metres below sea floor; $\mathrm{Cl}=$ clay, $\mathrm{Si}=$ silt, Vfs-fs = very fine sand-fine sand; Ms-vcs = medium sand-very coarse sand, $\mathrm{Gr}=$ gravel; Pleist. $=$ Pleistocene, Plio. $=$ Pliocene, Paleoc. $=$ Paleocene. Fossil occurrences are described in the Supplementary Material.

Figure 4. Comparative geochemical plots of mid-ocean ridge and subduction-related basalts. Comparison of samples from Site U1438 with global MORB ${ }^{29}$, Izu-Bonin-Mariana fore-arc basalts $(\mathrm{FAB})^{23,24}$, IODP Expedition $352 \mathrm{FAB}$ and boninite ${ }^{26}$, Site $1201^{21}$, and global MORB averages, with abbreviations: D, depleted; N, normal; E, enriched ${ }^{43}$. Y vs Zr abundances in basalts, noting High $\mathrm{Y} / \mathrm{Zr}$ is indicative of derivation of basalt from highly depleted upper mantle sources (a). V vs Ti abundances in basalts. Most MORB have $20<(\mathrm{Tippm} / 1000) / \mathrm{Vppm}<50$ whereas tholeiitic basalts in island arcs, including FAB, have (Tippm/1000)/Vppm $<20^{36}$. Some boninite from the Izu-Bonin-Mariana arcs have (Tippm/1000)/Vppm $<10^{26}$ (b). Additional data shown in Figures S3 and S4. 


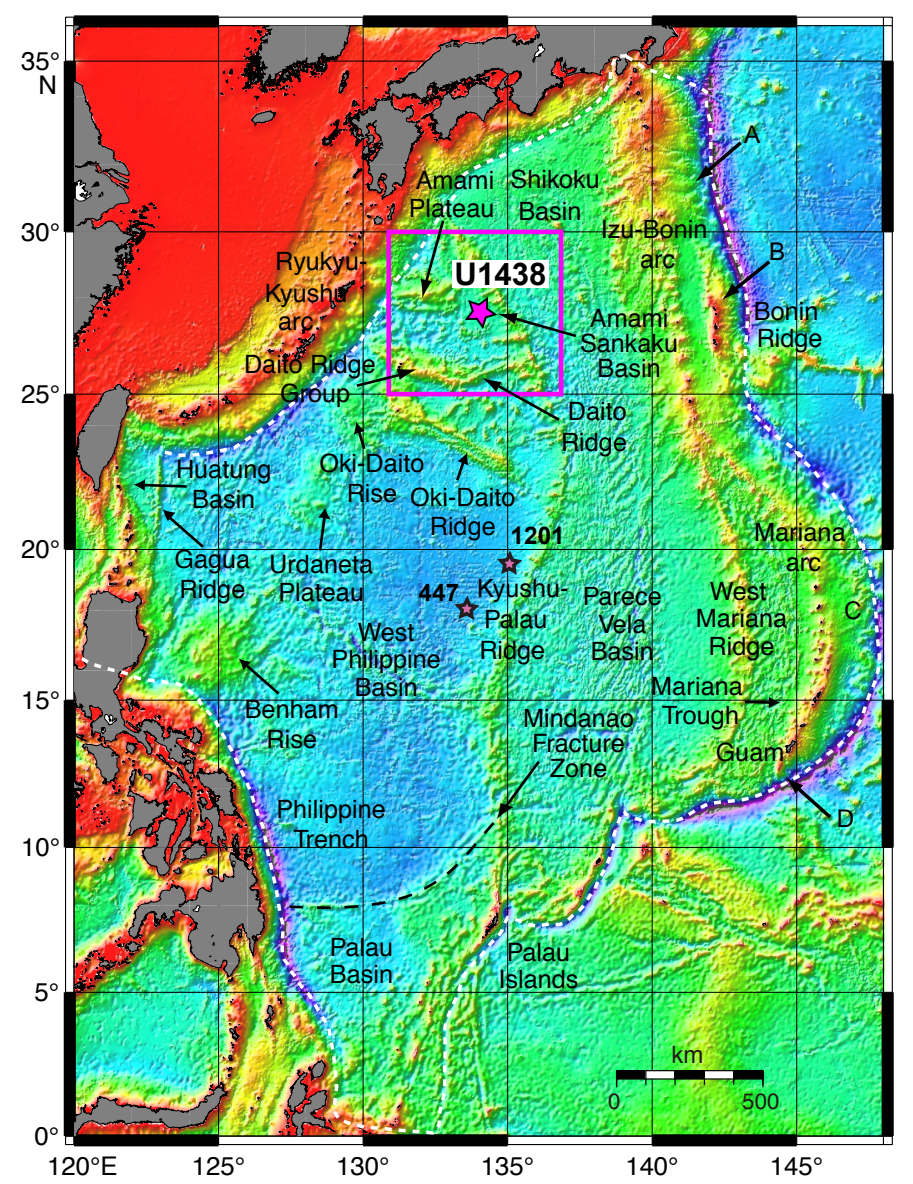



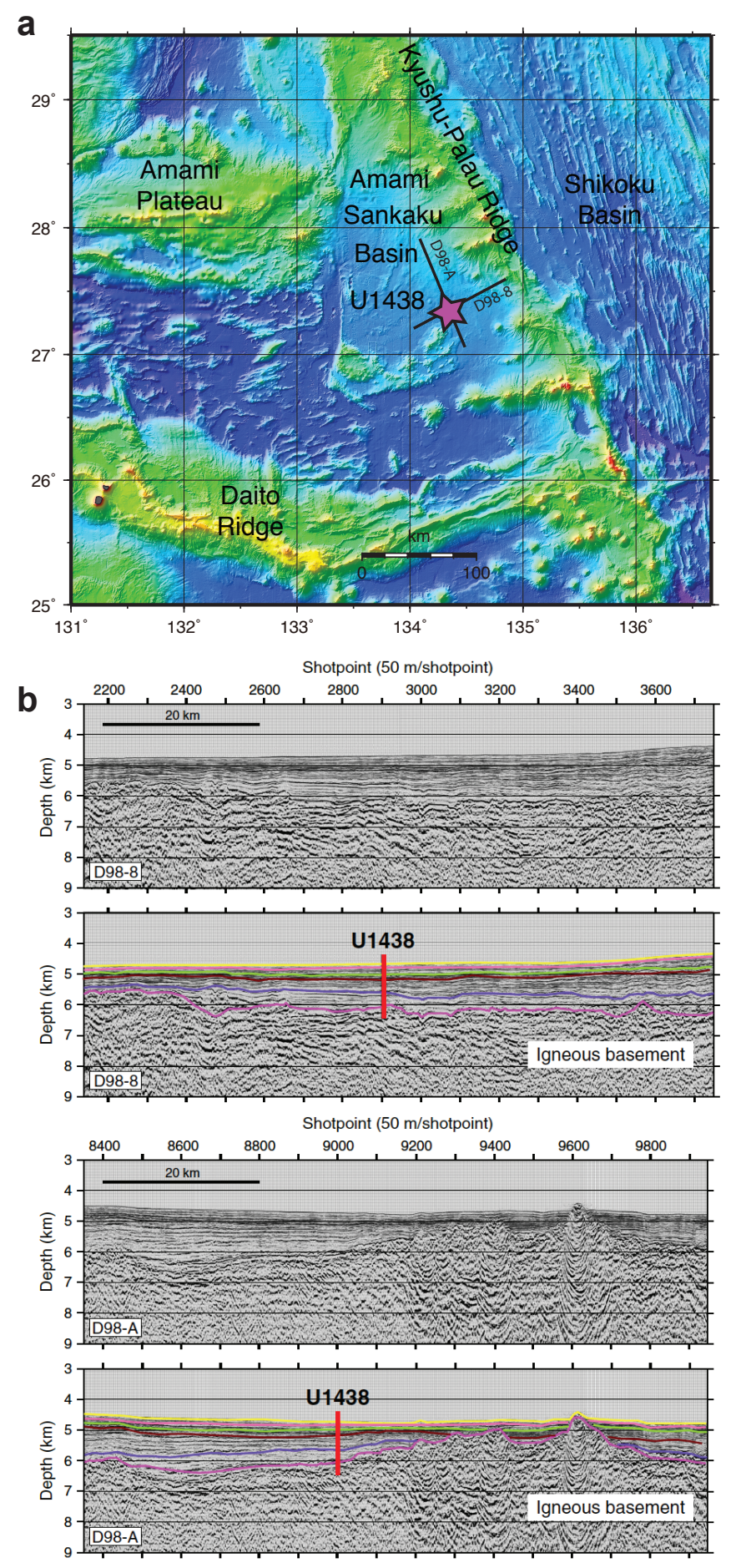


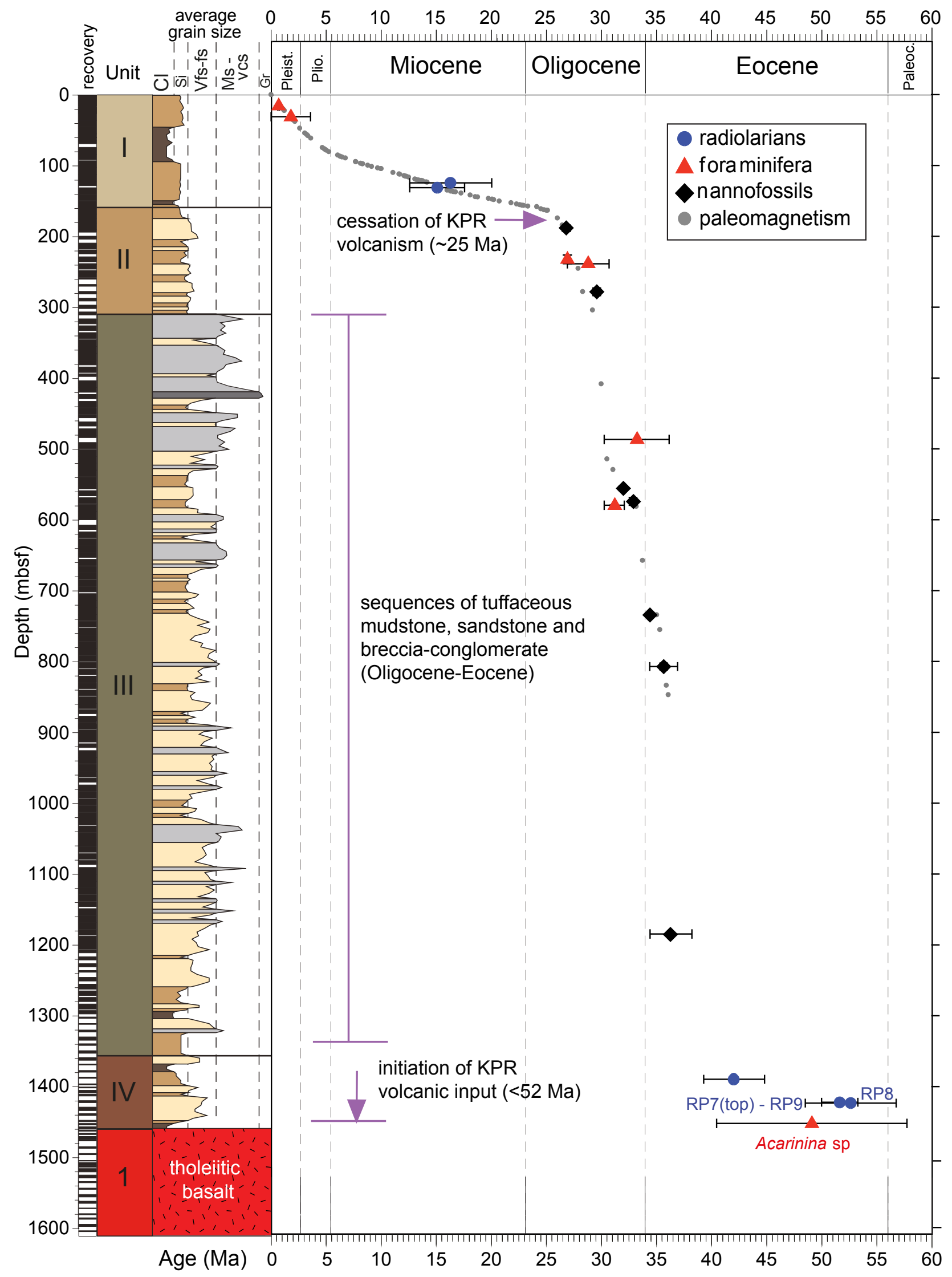



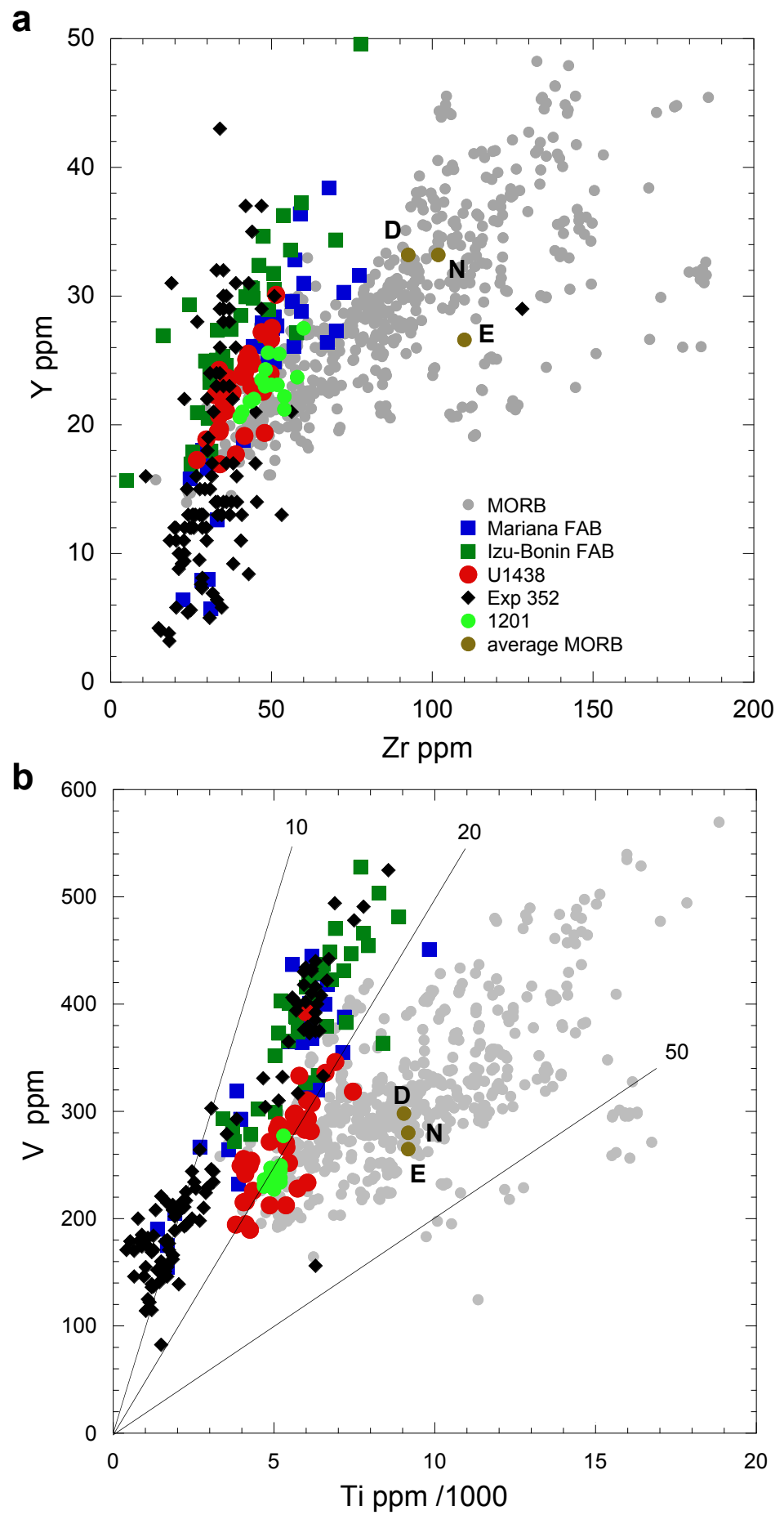


\section{Supplementary Information}

A record of spontaneous subduction initiation in the Izu-Bonin-Mariana $\operatorname{arc}$

Richard J. Arculus, Osamu Ishizuka, Kara A. Bogus, Michael Gurnis, Rosemary HickeyVargas, Mohammed H. Aljahdali, Alexandre N. Bandini-Maeder, Andrew P. Barth, Philipp A. Brandl, Laureen Drab, Rodrigo do Monte Guerra, Morihisa Hamada, Fuqing Jiang, Kyoko Kanayama, Sev Kender, Yuki Kusano, He Li, Lorne C. Loudin, Marco Maffione, Kathleen M. Marsaglia, Anders McCarthy, Sebastién Meffre, Antony Morris, Martin Neuhaus, Ivan P. Savov, Clara Sena, Frank J. Tepley III, Cees van der Land, Gene M. Yogodzinski, Zhaohui Zhang

\section{Contents}

S1 Seismic cross-sections

S2 Petrology of Unit 1

S3 Analytical Techniques for Shipboard ICP-AES

S4 Details of Unit IV lithology and paleontology

S5 Downhole temperature, thermal conductivity, heat flux, water depth and thermal age 


\section{S1 Seismic cross-sections}

The two-way travel times recorded by seismic reflection for the crossing lines D98-A and D98-08 (Fig. 2) through Site U1438 are shown in Figure S1.
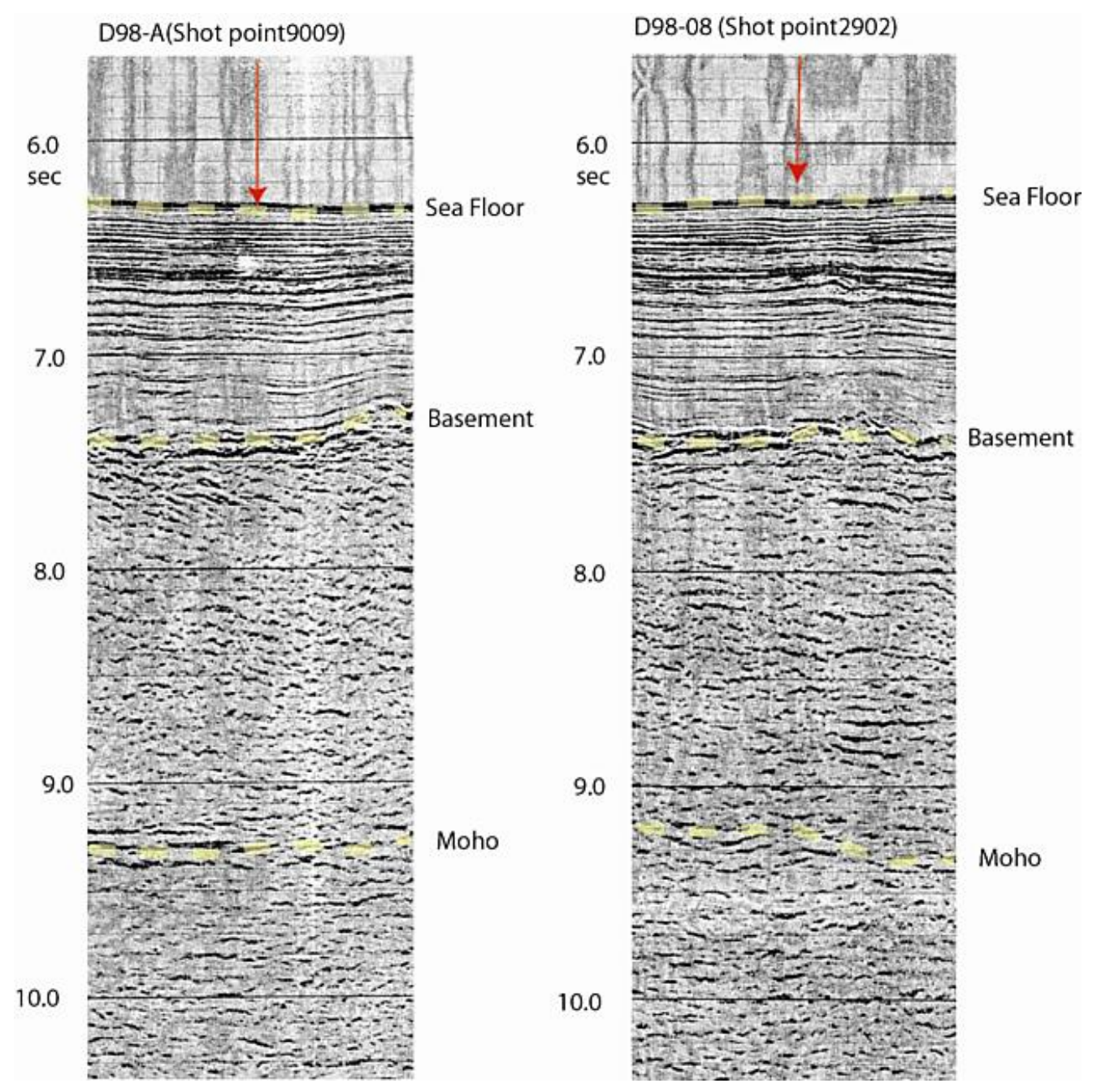

Figure S1. Details of the multi-channel seismic profiles (see Fig. 2 for location) that intersect at Site U1438. An estimate of the sediment-igneous basement interface and Moho location is indicated by yellow dashed lines. The vertical axis is two-way travel time in seconds.

\section{S2 Petrology of Unit 1}

The majority of phenocrysts in basalts of Unit 1, which comprises the Amami Sankaku Basin basement and lowermost lithostratigraphic unit of Site U1438, range in size from 0.2 to $4 \mathrm{~mm}$. Plagioclase phenocryst abundances range from $0 \%$ to $30 \%$, although $0-5 \%$ 
is predominant. The phenocrysts tend to be blocky and sometimes zoned. Clinopyroxene phenocrysts occur more rarely and tend to be smaller $(0.2 \mathrm{~mm})$ than plagioclase. The occurrence of olivine either as phenocrysts or in the groundmass is difficult to estimate due to strong alteration. Some olivine pseudomorphed by chlorite is recognizable by shape and the presence of small, partially translucent, reddish chrome spinel inclusions. The visible alteration consists predominantly of patchy chlorite and oxides replacing phenocrysts and groundmass, chlorite and carbonate filling sparse vesicles, and veins filled with chlorite + carbonate \pm sulfides and/or oxides. Vesicles are present in approximately one-third of the studied rocks but are usually sparsely distributed within each. The groundmass of the basalts is mostly holocrystalline and is composed primarily of plagioclase, clinopyroxene, and titanomagnetite. Glass can be significant in the groundmass (up to $85 \%$; average $=25 \%$ ), but is entirely altered mostly to chlorite. Representative photomicrographs are shown in Figure S2.

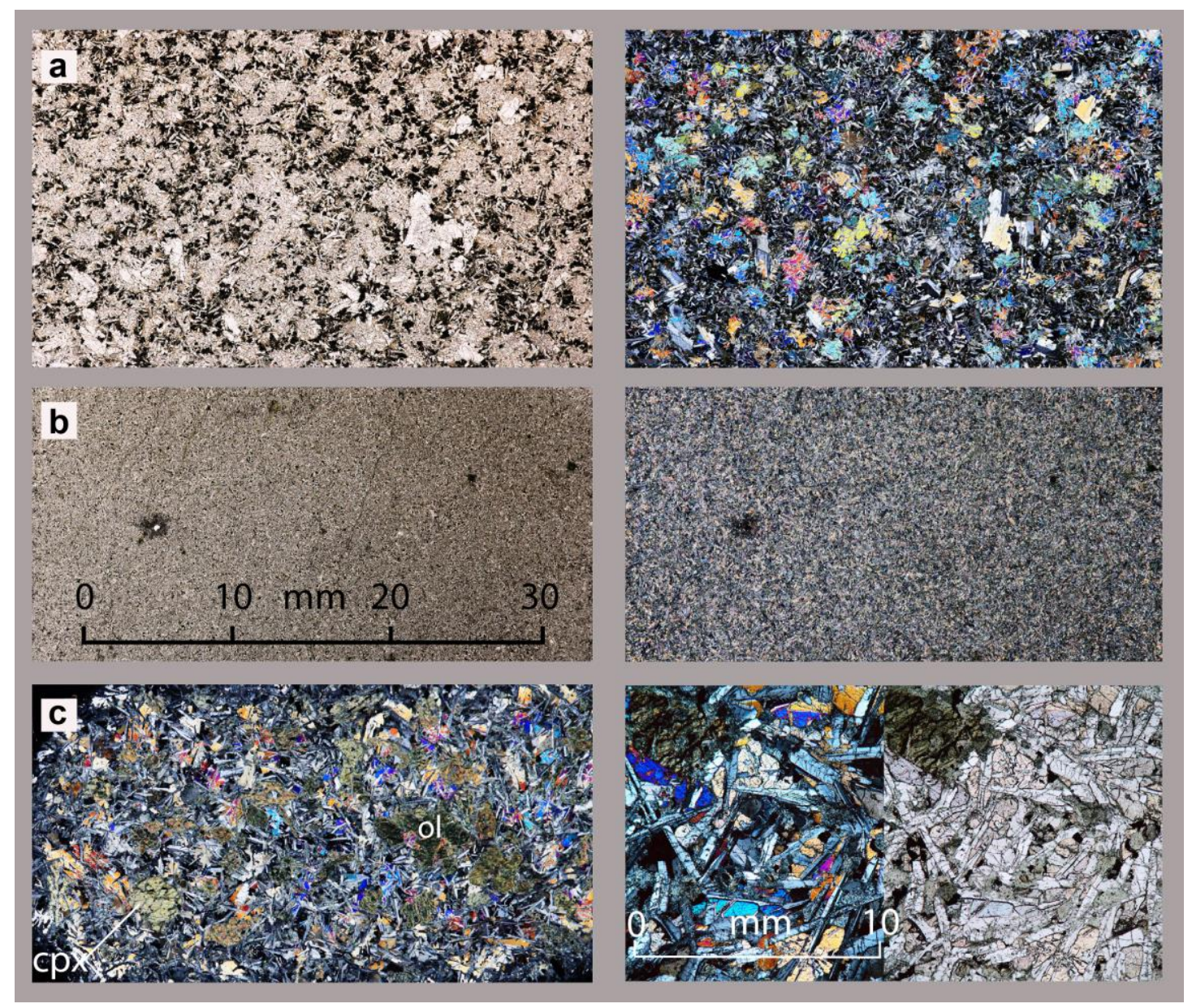

Figure S2. Whole thin section and detailed photomicrographs of Site U1438E Unit 1 basalts showing different textural types: a) fine-grained basalt with ophitic texture (351U1438E-78R-2); b) aphyric microcrystalline basalt (351-U1438E-77R-3); For a and b, 
views on the left are in plane polarized light and on the right are cross-polarized light. Horizontal dimension of the fields in all images except in bottom right panel is shown by the scale bar in (left). c) fine- to medium-grained basalt with ophitic texture, clinopyroxene (cpx) and altered olivine phenocrysts (ol) (351-U1438E-80R-1) on left, and details of same thin section on right with cross-polarized (left) and plane polarized (right). Scale bar is for both left and right of this image pair.

\section{S3 Analytical Techniques for Shipboard ICP-AES}

Thirty-seven samples from the Unit 1 basalts were collected (Cores U1438E-70R to 88R) and analyzed for major and trace elements by inductively coupled plasmaatomic emission spectroscopy (ICP-AES; Table S1). The majority of these samples are high-MgO (mostly >8 wt\%), low- $\mathrm{TiO}_{2}(0.6-1.1 \mathrm{wt} \%)$ tholeiitic basalts.

Samples $\left(\sim 2-8 \mathrm{~cm}^{3}\right)$ were cut from the core with a diamond saw blade with cut surfaces ground on a diamond-impregnated disk. The samples were cleaned ultrasonically in a beaker containing trace-metal-grade methanol (15 min), followed by deionized water (10 min), and then Barnstead deionized water (18 $\mathrm{M} \Omega \cdot \mathrm{cm} ; 10$ $\min )$. The cleaned pieces were dried for $10-12 \mathrm{~h}$ at $110^{\circ} \mathrm{C}$ and then crushed $(<1 \mathrm{~cm}$ chips) between two Delrin plastic disks in a hydraulic press. The chips were ground to a fine powder using a SPEX 8515 Shatterbox with a tungsten carbide lining. An aliquot of sample powder was weighed $(1000.0 \pm 0.5 \mathrm{mg})$ and then ignited $\left(700^{\circ} \mathrm{C}\right.$ for $4 \mathrm{~h}$ ) to determine weight loss on ignition (LOI). Ignited powders for each sample and standard were weighed (100.0 $\pm 0.2 \mathrm{mg}$; Cahn C-31) and mixed with $\mathrm{LiBO}_{2}$ flux ( $400.0 \pm 0.5 \mathrm{mg}$; pre-weighed on shore). Weighing errors were estimated as $\pm 0.05 \mathrm{mg}$ under relatively smooth sea surface conditions. Aqueous $\mathrm{LiBr}$ solution $(10 \mathrm{~mL}$ of $0.172 \mathrm{mM}$ ) was then added to the flux and powder mixture as a non-wetting agent. Samples were fused individually in Pt-Au (95:5) crucibles for $\sim 12 \mathrm{~min}$ at a maximum temperature of $1050^{\circ} \mathrm{C}$ in an internally rotating induction furnace (Bead Sampler NT2100). The beads were transferred into high-density polypropylene bottles, dissolved in a solution of $10 \% \mathrm{HNO}_{3}$ and $10 \mathrm{ppm} \mathrm{Ge}(50 \mathrm{~mL})$, and shaken on a Burrell wristaction shaker $(1 \mathrm{~h})$. Solution increments $(20 \mathrm{~mL})$ were passed through a filter $(0.45 \mu \mathrm{m})$ into a clean high-density polypropylene bottle. From the filtered solution, $1.25 \mathrm{~mL}$ was pipetted into a scintillation vial and diluted with $8.75 \mathrm{~mL}$ of a 
dissolution solution containing $10 \% \mathrm{HNO}_{3}$. The final solution-to-sample dilution factor is 4000:1.

Major (Si, Ti, Al, Fe, Mn, Mg, Ca, Na, K, and P) and trace (Sc, V, Cr, Sr, Y, $\mathrm{Zr}$, Ba) element concentrations of samples and standards were measured on a Teledyne Leeman Labs Prodigy ICP-AES instrument using multiple wavelengths commonly selected for silicate rocks, and instrument-specific start-up and peak search routines. Data were acquired using Gaussian peak fitting; each sample and standard was analyzed in quadruplicate within a given sample run. A $10 \% \mathrm{HNO}_{3}$ rinse solution was used (90 sec) between analyses. Thirteen certified rock standards (AGV-2, BCR2, BHVO-2, GSP-2, JB-2, JG-2, JG-3, JP-1, JR-1, JR-2, Nod-A-1, STM-1, VS-N) were used. Standard JB-2 is from the Izu-Bonin Arc, so it was analyzed as an unknown. Each run consisted of the standards interspersed with blanks and the samples in quadruplicate. Standard JR-2 was analyzed at the beginning and end of each run and interspersed in the sequence for instrument drift correction. Measured raw-intensities were corrected offline for instrument drift using the shipboard "ICP Analyzer" software. A linear calibration line for each element was calculated using the standards from which element concentrations in the samples were determined from relevant calibration lines. Calibration standards were analyzed in quadruplicate and yielded a precision of $\mathrm{Al}<0.4 \%, \mathrm{Ca}<0.6 \%, \mathrm{Fe}<0.5, \mathrm{~K}<0.6 \%, \mathrm{Mg}<0.5 \%$, $\mathrm{Mn}<0.6, \mathrm{Na}<1.5, \mathrm{Si}<0.4 \%$, and $\mathrm{Ti}<0.5 \%, \mathrm{Ba}<1.5 \%, \mathrm{Cr}<6.6 \%, \mathrm{Sr}<0.9 \%, \mathrm{Sc}$ $<1.6 \%, \mathrm{~V}<9.7 \%, \mathrm{Y}<1.0 \%$, and $\mathrm{Zr}<1.7 \%$. For major elements, data were rejected if volatile-free weight percentages totals were outside $100 \pm 5 \mathrm{wt} \%$ and are reported normalized to $100 \mathrm{wt} \%$ total. Blank solutions aspired during each run were below detection limits for all elements.

In addition to the data presented in Figure 4, we show equivalent plots (Figs S3 and S4) incorporating previously published analytical data for samples recovered by De Bari et al. ${ }^{22}$, at location A on Figure 1 (proposed to be equivalent to $\mathrm{FAB}^{24}$ ), and the 159 Ma samples recovered at location B on Figure $1^{23}$. 


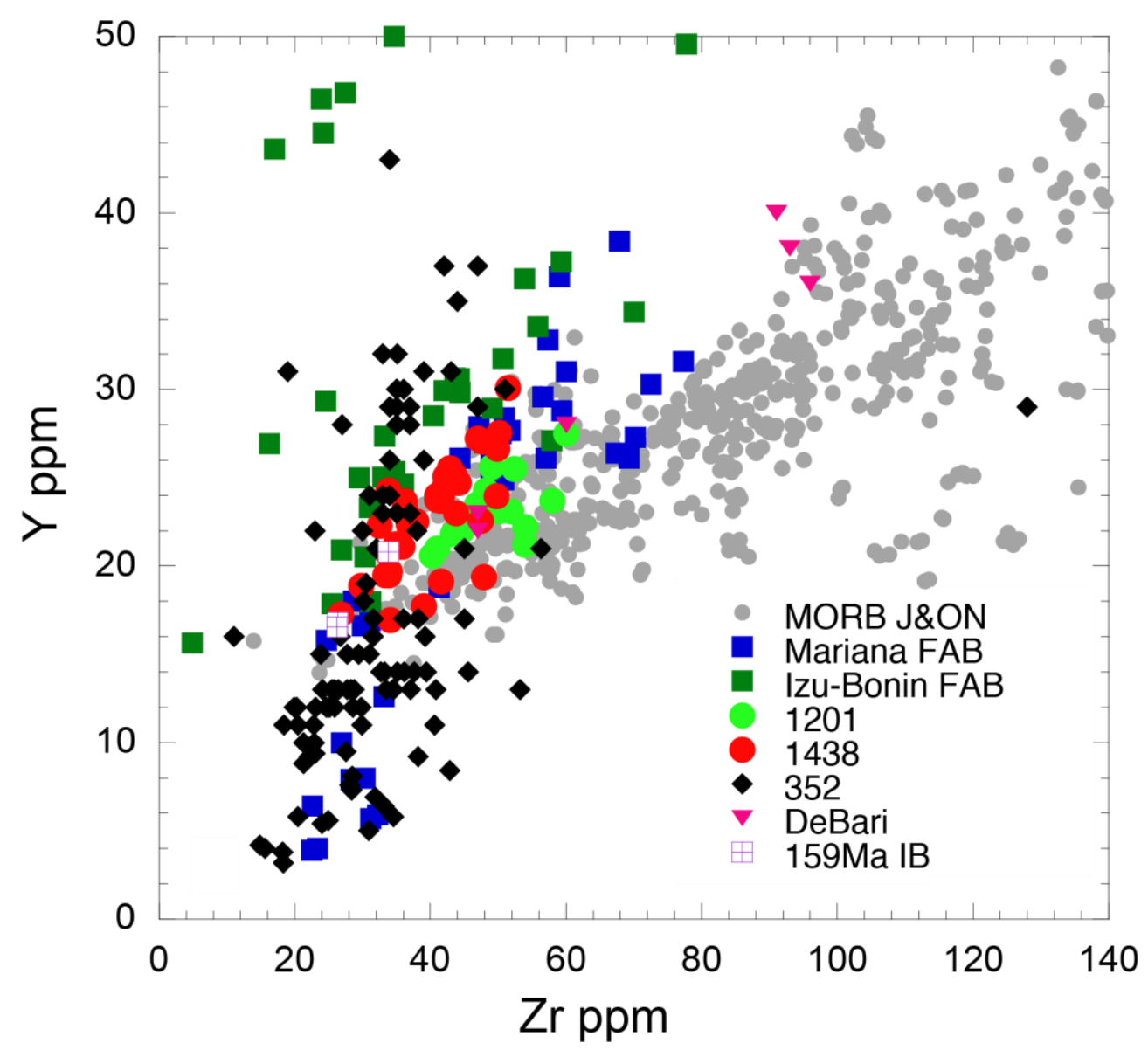

Figure S3. Comparison of $\mathrm{Zr}$ vs $\mathrm{Y}$ concentrations for samples from De Bari et al. ${ }^{22}$ and 159 Ma basalts from the IBM forearc ${ }^{23}$ with global MORB ${ }^{29}$, Izu-Bonin-Mariana fore-arc basalts $(\mathrm{FAB})^{23,24}$, Site $1201^{21}$, Site U1438, IODP Expedition 352 FAB and boninite $^{26}$. 


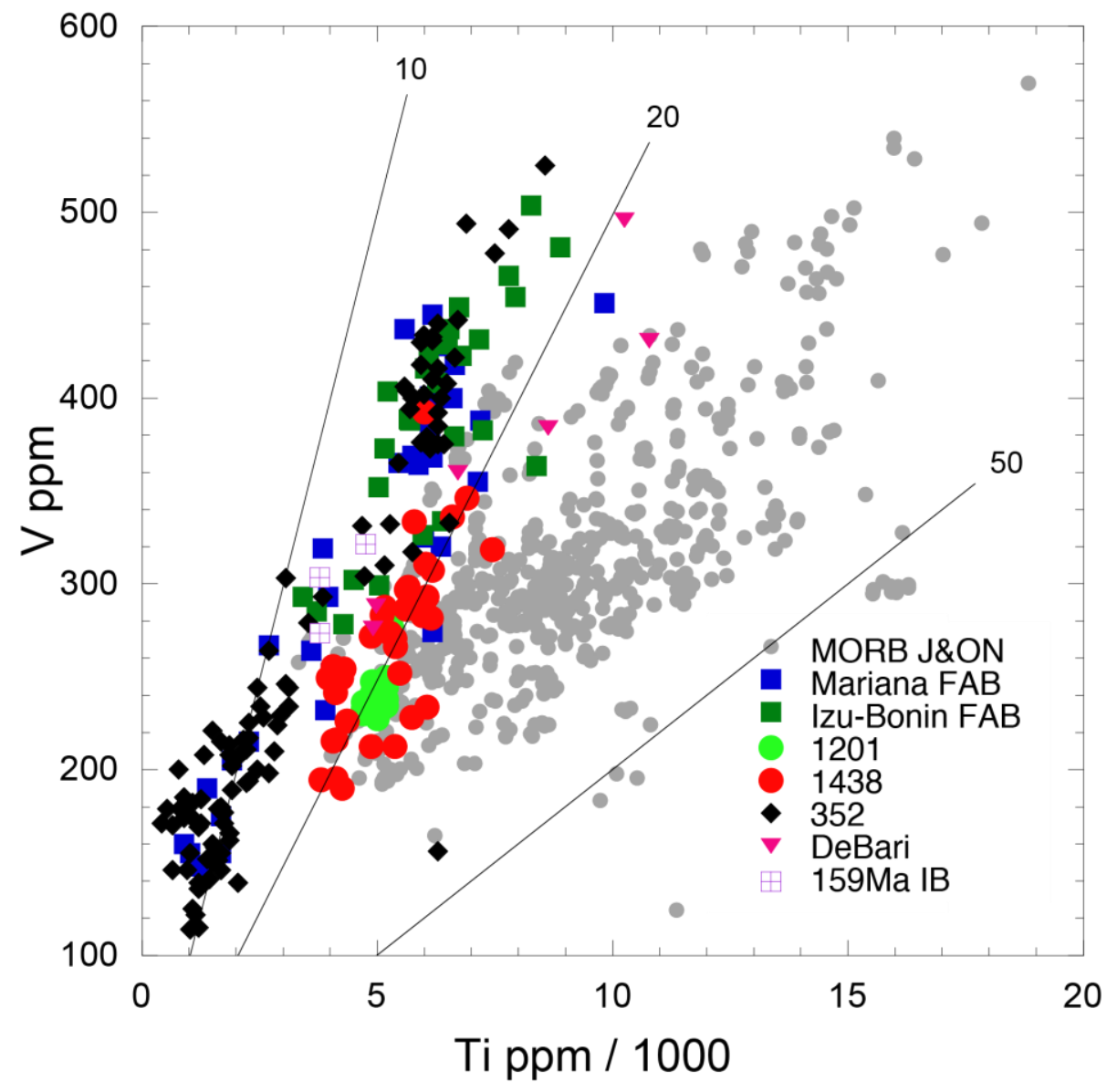

Figure S4. Comparison of V vs Ti concentrations for samples from De Bari et al. ${ }^{22}$ and 159 Ma basalts from the IBM forearc ${ }^{23}$ with global MORB ${ }^{29}$, Izu-Bonin-Mariana fore-arc basalts $(\mathrm{FAB})^{23,24}$, Site $1201^{21}$, Site U1438, IODP Expedition 352 FAB and boninite $^{26}$. Most MORB have $20<($ Tippm/1000)/Vppm $<50$ whereas tholeiitic basalts in island arcs, including $\mathrm{FAB}$, have $(\mathrm{Tippm} / 1000) / \mathrm{Vppm}<20^{36}$. Some boninite from the Izu-Bonin-Mariana arcs have (Tippm/1000)/Vppm $<10^{26}$.

Table S1. Analytical results for samples from Unit 1, Site U1438

\section{S4 Details of Unit IV lithology and paleontology}

The lithology at Site U1438 consists of sediments, sedimentary rocks, and igneous rocks (Fig. 3). Sediments and sedimentary rocks at Site U1438 were recovered from the seafloor to 1461 meters below seafloor (mbsf) and are divided into four lithostratigraphic units. Unit I (160.3 m thick) is recent to latest Oligocene in age and the sediments are primarily terrigenous, biogenic, and volcaniclastic mud and ooze with interspersed discrete ash layers. Unit II (139.4 m thick) is Oligocene in age and the sedimentary rocks are tuffaceous mudstone, siltstone, and fine sandstone with 
localized slumping-induced deformation features. The mudstone to sandstone intervals are typically normally-graded beds with sharp lower boundaries to the sandstone bases, as well as moderately to strongly bioturbated mudstone caps. Unit III (1046.4 m thick) is Oligocene to Eocene in age; the sedimentary rocks are generally coarser grained than those of Unit II and include tuffaceous mudstone, tuffaceous sandstone, tuffaceous medium to coarse sandstone with gravel, and tuffaceous breccia-conglomerate with volcanic and sedimentary clasts commonly up to pebble and (rarely) cobble size. At the largest scale, Unit III comprises five intervals of coarser clastic sedimentary rocks, separated by intervening mudstone-dominant intervals lacking discrete breccia-conglomerate beds. Unit IV (99.7 m thick) and is Eocene in age. It is composed of radiolarian-bearing mudstone underlain by medium to coarse sandstone, breccia-conglomerate, and tuffaceous siltstone and mudstone. The centimeter- to decimeter-scale layers of sandstone range in color from dark greenish gray to very dark gray, and exhibit normal grading, lamination, and cross lamination. These intervals consist of common to abundant volcanic rock fragments exhibiting microlitic to vesicular to pumiceous textures, in addition to rounded to subangular grains of plagioclase, pyroxene, amphibole, and opaque minerals. There are some black, tachylitic glass fragments with plagioclase microlites.

Siltstone/mudstone fragments are rare. The feldspar, ferromagnesian minerals, and volcanic grains are variably altered to zeolites and clay minerals (which also occur as cementing phases), although clinopyroxene grains are mostly unaltered. Alteration minerals include chlorite-clay, zeolite, hematite, and titanite. In the sandstones $10 \mathrm{~m}$ above basement, laminae are unusual in that they are crystal-rich (predominantly plagioclase and green amphibole) with amphibole-bearing, felsic groundmass volcanic fragments. Three high-Na basaltic andesite sills intrude the sediments between $49-55 \mathrm{~m}$ above the basement. The sills are sparsely phyric, with 3\%-5\% phenocrysts and microphenocrysts of clinopyroxene $(0.2-1.0 \mathrm{~mm})$ set in a groundmass of devitrified glass with microlites of plagioclase and pyroxene. The sole presence of clinopyroxene phenocrysts distinguish the sills from basalts of the underlying basement. There is no evidence in the oldest sediments for a large component of clastic material derived from uplifted subjacent basement as expected from induced subduction. There is also no evidence for any intense regional deformation of the sediments other than some minor faulting. Unit IV is underlain by igneous basement rocks comprising Unit 1 (See Section S1 for characteristics). 
Radiolaria are present in the 4 m-thick mudstone and sandstone section above basement, but are nondeterminable in age. The oldest sample yielding determinable radiolaria is $40 \mathrm{~m}$ above basement (Fig. S6). The assemblage contains radiolarian genera characteristic of the latest Paleocene-early Eocene. Based on the presence of Buryella spp., Phormocyrtis spp., Podocyrtis spp., and Theocotylissa spp., the age of the sample is tentatively interpreted as latest Thanetian-Ypresian (RP7 [top]-9; 56.83-48.57 Ma). A sandy sample from Section 66R-CC, $12 \mathrm{~m}$ above basement, contains two specimens of very poorly preserved, partially recrystallized planktonic foraminifers. One specimen probably belongs to the species Acarinina bullbrooki (Zones E7-E11; 50.2-40.49 Ma), or possibly Acarinina soldadoensis (Zones P4c-P9; $57.79-44.49 \mathrm{Ma})^{1}$. 

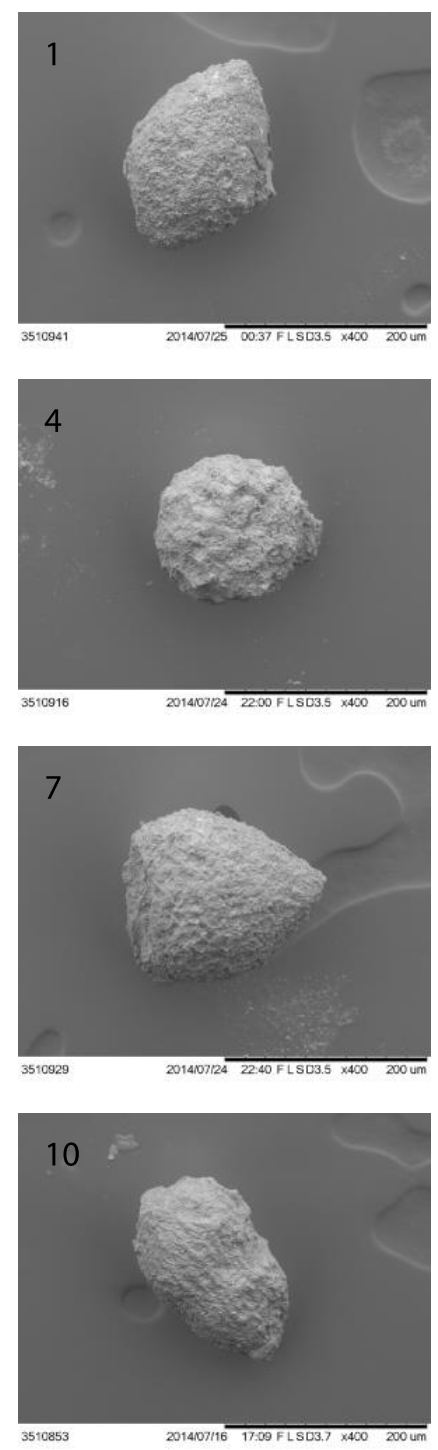
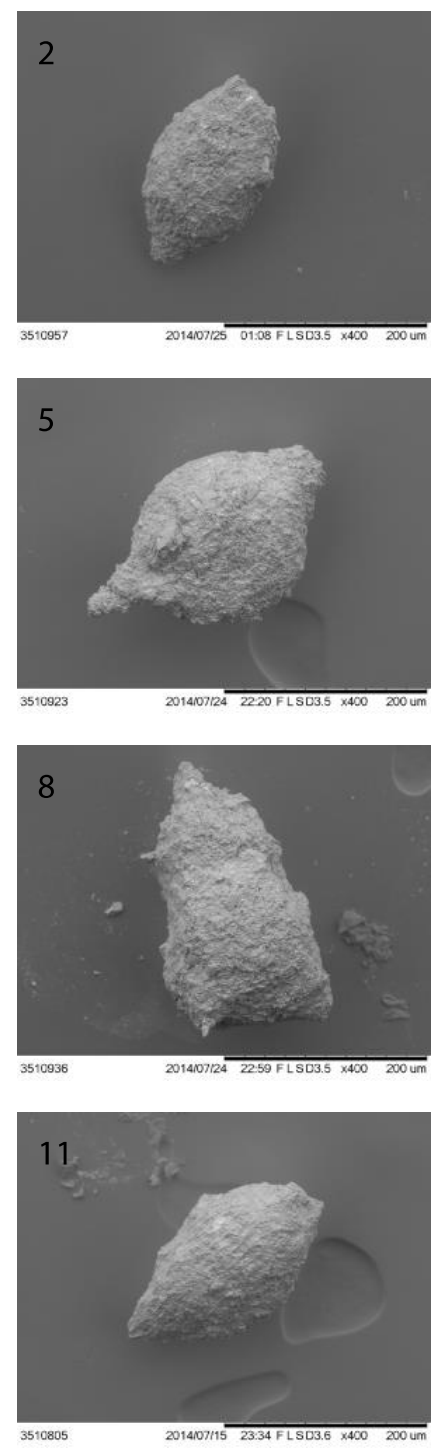
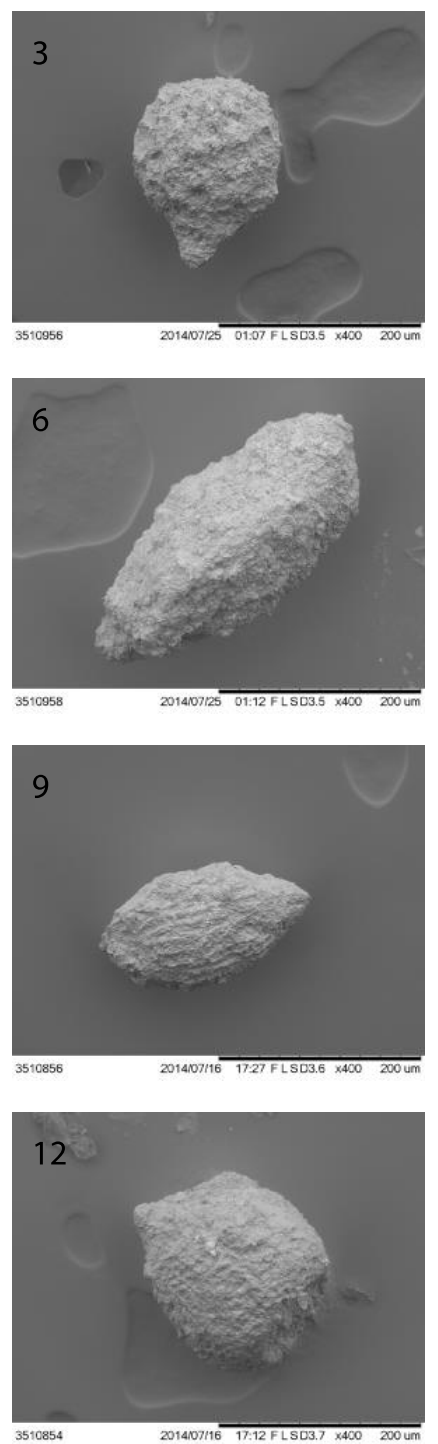

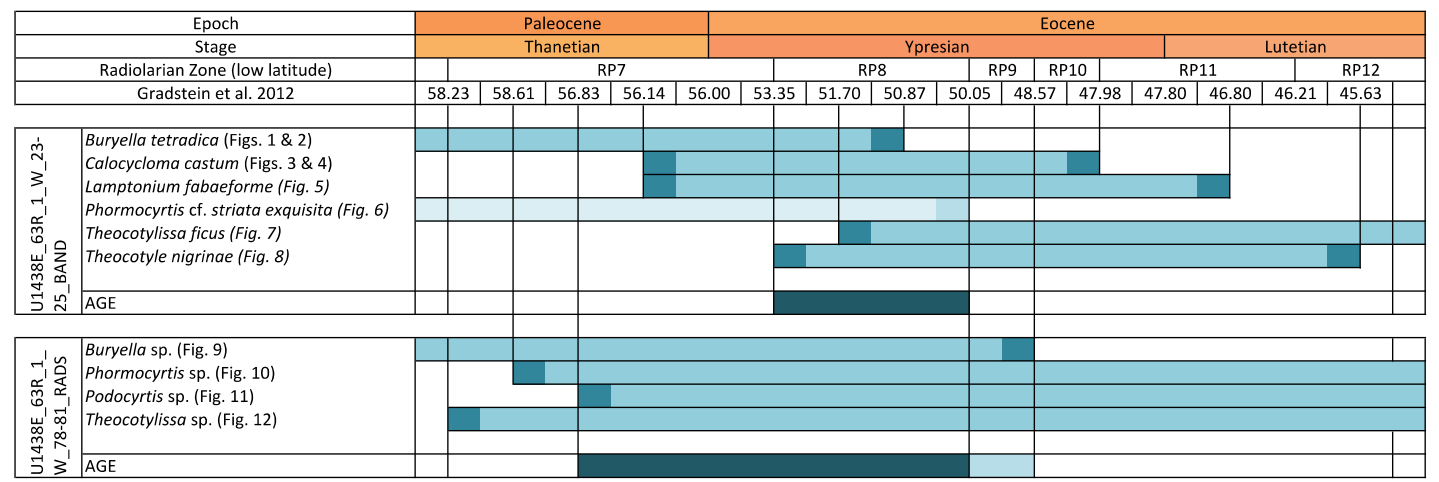

Figure S5. Scanning electron microscope images of radiolarians from Unit IV of Site U1438 and genera ranges used to constrain the age (lower panel). Sample U1438E63R-1W, 23-25 cm (Early Eocene): 1 and 2. Buryella tetradica; 3 and 4. Calocycloma castum; 5. Lamptonium fabaeforme; 6. Phormocyrtis cf. striata exquisita; 7.

Theocotylissa ficus; 8. Theocotyle nigrinae. Sample U1438E-63R-1W, 78-81 cm 
(latest Paleocene-Early Eocene): 9. Buryella sp.; 10. Phormocyrtis sp.; 11. Podocyrtis sp.; 12. Theocotylissa sp.

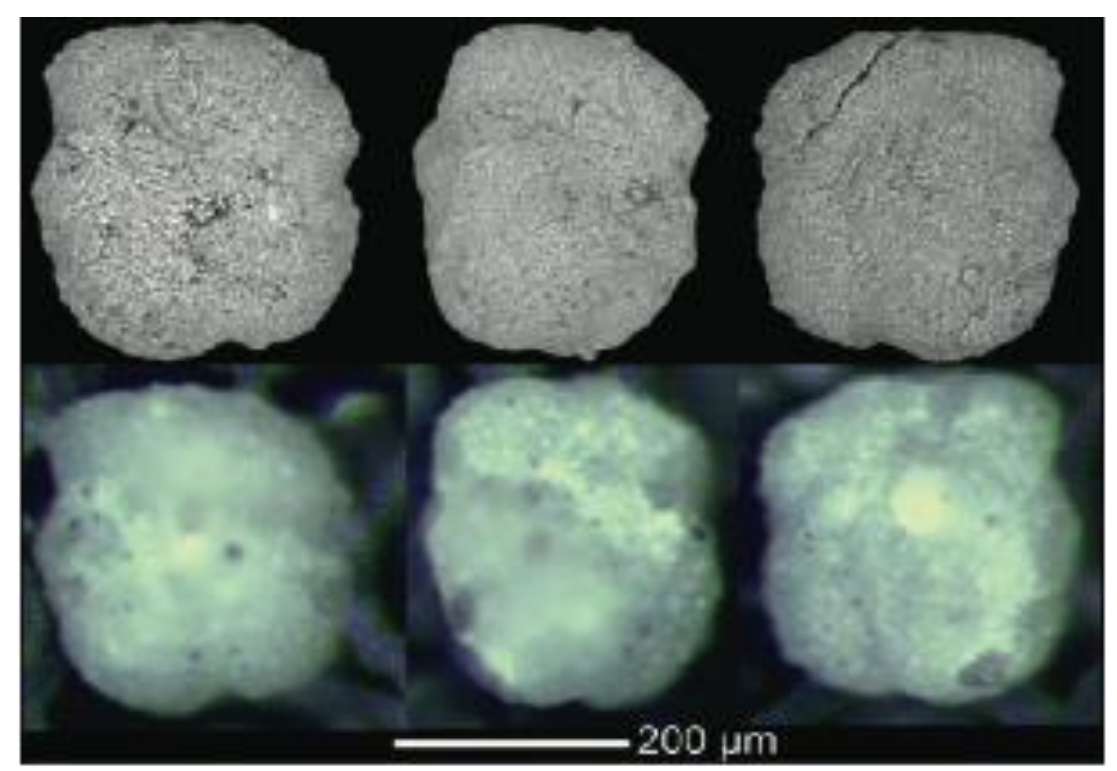

Figure S6. Scanning electron microscope (upper) and reflected light (lower) images of Acarinina sp. from Sample U1438E-66R-CC.

\section{S5 Downhole temperature, thermal conductivity, heat flux, water depth and thermal age}

Successful temperature measurements were made at seven depths using the advanced piston corer temperature tool (APCT-3) ${ }^{2}$ from the mudline to $83.2 \mathrm{mbsf}$. The temperatures as a function of depth did not show any substantial deviation from a linear geothermal gradient of $77.6^{\circ} \mathrm{C} / \mathrm{km}$ (Fig. S7). Thermal conductivity was measured using the Teka TK04 system by transient heating of the sample with a known heating power and geometry ${ }^{3}$. Changes in temperature with time during heating are recorded and used to calculate thermal conductivity. At these depths, the sediment was poorly consolidated, so a needle probe was inserted into the sediment through a $2 \mathrm{~mm}$ hole, drilled into the plastic core liner, to measure the thermal conductivity. All measurements were subsequently corrected for in situ conditions using the method of Hyndman et al. ${ }^{4}$ in which the temperatures were determined from the interpolated APCT-3 measurements (Fig. S7a). Spurious values with $\mathrm{k}_{\mathrm{s}}<0.85$ $\mathrm{W} /[\mathrm{m} \cdot \mathrm{K}]$ from each set of three individual measurements were removed and the mean and standard deviation determined. Overall, there were 28 measurements of the core approximately evenly spaced down to 100 mbsf. The measurements did not vary 
substantially from a constant value of $0.951 \pm 0.046 \mathrm{~W} / \mathrm{mK}$ (Fig. S7b). A combination of the temperature measurements with the thermal conductivity using Bullard-type analysis ${ }^{5}$ indicated the thermal gradient did not change with depth in the upper part of Site U1438 (Figure S7c). This suggests a geotherm that is undisturbed by local processes, such as sediment compaction, fluid flow within the porous sediments, or internal heat production from radioactive decay. With these measured thermal conductivities, the calculated heat flux is $73.7 \mathrm{~mW} / \mathrm{m}^{2}$ (Figure S7d). The intersection of the measured heat flux with the empirical plate age-reliable heat flow relation ${ }^{25}$ occurs at $50 \mathrm{Ma}$. Given the range of the individual heat flow values and uncertainty in basement age for each reliable heat flow value, a conservative estimate for the thermal age of the ASB is 40-60 Ma. This estimate is independent of the use of a plate model or a half space model when interpolating between reliable heat flow values.

A preliminary estimate of the sediment load-corrected depth of the basement at Site U1438 gives a depth of $\sim 5527 \mathrm{~m}$. A residual depth of $\sim 550 \mathrm{~m}$ is calculated from an expected depth of $5000 \mathrm{~m}$ for a $50 \mathrm{Ma}$ age plate $^{6}$. This is consistent with other estimates for the west Philippine Sea Plate and within the range observed for the Shikoku and Parece Vela basins, which have excess depths of 500-1000 $\mathrm{m}^{7}$. In other words, the entire region around Site U1438 has water depths greater than predicted by the average subsidence of the sea floor and is interpreted as a dynamic draw-down by mantle flow. The water depths suggest that the age of the plate might be slightly younger than the $50 \mathrm{Ma}$ thermal age, but, at a minimum, the heat flux and water depth give ages consistent with that inferred from biostratigraphy. 

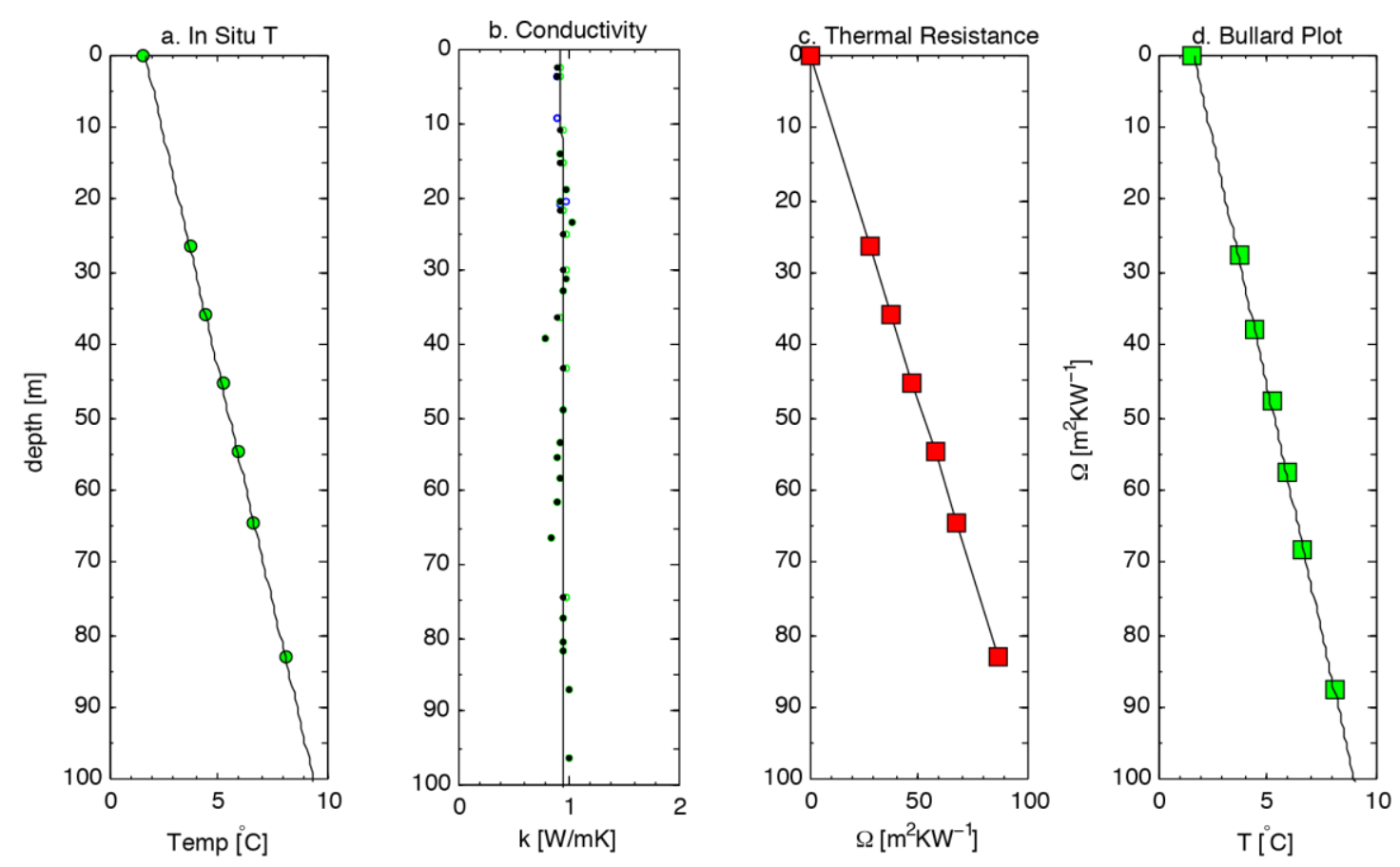

Figure S7. Temperature gradient, conductivity, thermal resistance, and Bullard plot for data obtained with the advanced piston corer temperature tool at Site U1438.

\section{References}

1. Pearson, P.N., et al. Atlas of Eocene Planktonic Foraminifera. Cushman Foundation for Foraminiferal Research, Fredericksburg, USA, Cushman Foundation Special Publication 41513 pp (2006).

2. Heesemann, M. et al. Data report: testing and deployment of the new APCT-3 tool to determine in situ temperatures while piston coring. Proc. Integrated Ocean Drill. Program 311, 1-19, doi:10.2204/iodp.proc.311.108. (2006).

3. Blum, P. Physical properties handbook. ODP Tech. Note, 26. doi:10.2973/odp.tn.26. (1997).

4. Hyndman, R.D. et al. Geothermal measurements on DSDP Leg 26. Proc. DSDP Init. Repts. 26, 451-463 (1974).

5. Bullard, E.C. Heat flow in South Africa. Proc. R. Soc. London A 173, 474-502 (1939).

6. Sclater, J.G., Jaupart, C. \& Galson, D. The heat flow through oceanic and continental crust and the heat loss of the Earth. Revs. Geophys. Space Phys. 18, 269-311 (1980).

7. Winterbourne, J., White, N. \& Crosby, A. Accurate measurements of residual topography from the oceanic realm. Tectonics 33, 982-1015 (2014). 